\title{
The Model for Implementing Bureaucratic Reform in the Ministry of Administrative Reform
}

\author{
Hendrikus Triwibawanto Gedeona*, Endang Wirjatmi Trilestari \\ Public Administration Department \\ Politeknik STIA LAN Bandung \\ Bandung, Indonesia \\ *hendrikusgedeona@gmail.com
}

\begin{abstract}
President Jokowi-Amin's administration (20192024) continues to make bureaucratic reform on of Indonesia's development priorities. Currently, the steps being taken are bureaucratic downsizing. Administrative positions (echelon III and IV) were removed and replaced with certain functional positions, as was done by Ministry of Administrative Reform. The hope is that the bureaucracy will be more agile, dynamic, focused on functional work and high performance. The strategic steps taken are identifying administrative positions in work units, mapping positions and administrative officials affected by bureaucratic downsizing, mapping functional positions that can be occupied by officials affected by bureaucratic downsizing, aligning functional position allowances with administrative position allowances by calculating income from administrative positions to positions classes. In the process, there are obstacles faced, namely the availability of functional positions in the work field is still incomplete, only policy analysts; worries about losing positions and income; public servant career paths that have not been developed properly; public servant career maps that have not been developed properly; competency standard instruments at the level of certain functional positions do not yet exist; the work mechanism of the new bureaucratic structure model has not been developed; the mental readiness of work and the capacity of functional officials are equalized. Various obstacles cause the effectiveness of the goal of bureaucratic downsizing cannot be assessed at the beginning of the implementation of this bureaucratic reform.
\end{abstract}

Keywords-implementation of bureaucratic reform, downsizing bureaucratic

\section{INTRODUCTION}

The administration of President Jokowi-Amin at the Parliament Building on September 20, 2019 delivered the 2019-2024 priority programs which include the development of Indonesian human resources, infrastructure development, simplification of all forms of regulation and economic transformation, the stage budget is right on target and bureaucratic reform. Notwithstanding the importance of other priority programs, an interesting issue that has received the attention of researchers is related to bureaucratic reform.
We all know that the issue of bureaucratic reform never seems to be resolved. Since the Reform Era that started in 1998 until now, it has been around 22 years. The issue of bureaucratic reform remains an actual and important issue for the government in power every period. Not because of the formality of the government but the fact that there are many problems and homework in the bureaucracy that must be fixed with various challenges that vary from time to time.

In the current President Jokowi-Amin administration, the issue of bureaucratic reform has become a priority development program. The focus of attention of the JokowiAmin Government is related to cutting the bureaucracy, especially in administrator positions (echelon III) and supervisory positions (echelon IV). The direction of this bureaucratic reform program was then followed up by Ministry of Administrative Reform, by downsizing bureaucracy at Ministries and Institutions in the Central Government and Regional Government. Ministry of Administrative Reform as the implementer is a pioneer in implementing this policy.

The most important issues that has become the main issue in carrying out bureaucratic reform, including during the Jokowi-Amin administration, is the problem of work ineffectiveness and government performance.

Secondary data shows that the effectiveness of work and government performance are the main issues of various research conducted by credible institutions, both national and global. For example, the results of research conducted by the World Bank 2019 show that the Indonesian Government Effectiveness Index (GEI) ranks $95^{\text {th }}$ (score 54.81) lose to compete with other ASEAN countries such as Malaysia, Singapore, Thailand, and Philippines. The GEI scores and rankings are still far from the ideals required by the World Bank to go to Upper-Middle Income Countries (the score requirements are greater than 80 and are at least in the $35^{\text {th }}$ rank). This means that the GEI, which is owned by the Government of Indonesia, must be fixed, or improved from time to time [1].

The World Bank indicators in assessing the effectiveness of government include quality of public services; civil service 
quality; independence from political pressure; quality of policy formulation and implementation; and the credibility of the government's commitment to implementing the policies implemented. This means that on these various indicators, the Indonesian Government must make future improvements to increase the GEI.

Apart from the World Bank report, internal national data also shows that the performance of the government, both the central government and local governments, still has many problems. For example, if we look at the Government Agency Performance Accountability System (SAKIP) and the Government Agency Performance Accountability Report (LAKIP) submitted by Ministry of Administrative Reform. There are still many government agencies that get unsatisfactory scores regarding this SAKIP and LAKIP of the 84 ministries/institutions with 418 work units, 34 provincial governments with 1,027 Local Apparatus Organizations (OPD), and 514 districts/cities with 20,756 OPDs in 2019. LAKIP scores for Ministries and Institutions are mostly BB and $\mathrm{B}$, while in the regions are even worse, most of them score $\mathrm{CC}$ and $\mathrm{C}$. This indicates that the systems for the use and management of the budget effectively of governance, both Central and Local, are still not optimal [2].

In addition, data from the study results from LAN RI 2018 show that are six internal problems faced by the government bureaucracy so that the effectiveness of the government is not good, namely: (1) unequal interaction between government and non-government in regulating and managing public affairs and interests; (2) weak government capabilities; (3) public organizational structures that create siloization and are fragmented; (4) public policy products that are not evidencebased; (5) public service products that are not responsive and are not oriented towards public needs; (6) a public bureaucracy that is not impartial [3].

Apart from the problems above, especially those related to public services, it seems that the government bureaucracy is also experiencing serious problems. For example, in the context of the ease of doing business in Indonesia. The World Bank reports 2018 that Indonesia is ranked $72^{\text {nd }}$ in the ease of doing business. Especially in comparison to other ASEAN countries such as Singapore, Malaysia, Brunei, and Vietnam. The problem lies in licensing regulations and moral hazard from public servants [4].

Besides the internal bureaucratic problems described earlier, the Indonesian Government Bureaucracy is also faced with various dynamics of changes in the external environment. The strategic issues that can be identified include: First, global megatrends. The global megatrend phenomenon, in turn, has a significant impact on every country in pursuing development goals and the welfare of its people. KPMG 2016, a study institute based in Switzerland explained that "...nine global megatrends that are most salient to the future of governments and their core responsibilities of economic prosperity, security, social cohesion and environmental sustainability. While their impacts will be far-reaching, the trends are highly interrelated.
Therefore, governments will need to consider and evaluate their impacts both in isolation and in combination... possible options for governments to consider using the core tools available - policy, regulation and programs - as well as the strategies, structures and skills that future governments will need to have in place to achieve the characteristics of a 'leading practice' government in the future [5]'. This means there are nine global megatrends which, either directly or indirectly, have an impact on the roles, functions, and responsibilities of the government, especially in the fields of economic welfare, security, social cohesiveness, and environmental sustainability, as well as other fields that become contextual needs for a country. Thus, in this context, changes to policies, regulations and priority programs are needed, in addition to substantive changes in the state/public administration related to government strategy, structure, and competence. The 9 (nine) trends of global change that occur include: (1) demographic changes, (2) increasing individual demands and needs, (3) technological developments that change the socio-political-economic order, (4) economic attachment or dependence between countries, (5) increasing state debt and demands for the government to ensure the availability of public goods, (6) shifting of economic power from the American-European region to the Asian region, (7) climate change, (8) a crisis in the availability of natural resources, and (9) urbanization [5].

Second, the industrial revolution 4.0 or also known as the digitalization era. The world today, especially the industrial world, has undergone very basic changes. New methods and platforms are formed based on technology, from industrial civility to digital technology. It was the era where everything old, whether it is a product, a brand, or a way of working (business process) fell. There is disruption everywhere. When the beginning occurred, all of humanity was shocked by the incident. Because everything is completely unstable and chaotic. However, as time goes on, things began to calm down. Stability can be obtained. The various shifting events that occurred because of a disruption in this 4.0 revolution era are not small. The impact is very significant for human civility in the world, including Indonesia. What we need to pay attention to is that disruption does not only cause a shifting effect, but also a very large psychological effect for the industrial world and society in general in the world. The digitization that occurs with the presence of sophisticated technology has fundamentally changed the old platform to completely online. In this context, a new civility is certainly born and demands various kinds of changes from society.

We know that the industrial revolution 4.0 has brought 9 types of technology as the main pillars in developing various businesses and industries to move towards the era of digitalization. Those 9 (nine) types of technology are: (1). Internet of things; (2). Big data; (3). Augmented reality; (4). Cyber Security; (5). Artificial Intelligence; (6). Additive Manufacturing; (7). Simulation; (8). System Integration; and (9). Cloud Computing. All of these, of course, is homework that we still must do today and perhaps in the future [6] 
Third, the Demographic Bonus. This strategic issue has also caught my attention because many people think that this demographic bonus is a gift that will immediately come and will become a fundamental asset for developing the state, without realizing that the quality of our human resources is still low. It is possible that in 2035 , Indonesia will receive a lot of bonuses for productive age human resources, but quality should be a major issue that needs attention and a challenge to find a solution. Why? Because based on the 2017 Global Human Capital Report [7] it shows that the quality of our Indonesian human resources is ranked 65 out of 113 countries. This level of quality is relatively low when compared to neighbouring countries, such as Singapore (11th), Malaysia (33rd), Thailand (40th), and the Philippines (50th). In other words, it can be concluded that in the next 15 years or so, the Government of Indonesia is required to be able to increase human resources competence in line with the needs of the labour market, jobs and also the demands of the Industrial Revolution 4.0 and the global megatrends that have occurred.

Fourth, is the Covid-19 Pandemic. The actual problem that is currently hitting the world, including our country, is of course the thing that triggers various fundamental changes in human life. It is The Covid-19 virus, which has killed so many humans, for which a cure and vaccine has not been found, and it has changed civility in human interactions. WHO initiated a new concept called new normal, which in the Indonesian context is interpreted as a new normal life order. This new normality simply puts the Indonesian people to be "at peace with Covid-19" to return to their activities in every aspect of life, especially economic activities, by strictly adhering to health protocols.

This phenomenon, in the present context, has been applied, and according to Abdullah [8], Professor of Anthropology, Faculty of Humanities, Gadjah Mada University, it was emphasized that the new normal has implications or concerns of two things that must be considered, namely: new normal as a cultural statement and new normal as a precedent. In the first aspect, the new normal as a cultural statement means that the existence of Covid-19 presents a big question about how strong is Indonesian culture elastic in entering the new normal era? Does our culture have sufficient resilience so that it can accompany and guide people to deal with the new normal era? These are the questions that are important to answer. In the second aspect, the new normal as a cultural precedent becomes a historical momentum because many parties are taught something new in every dimension of people's lives and are required to adapt and make changes in behaviour towards these new things. Abdullah [8] has the view that from normal to new normal is new civility. All are not at the old normal and naturally adapt. And, in this context, the bureaucracy is obliged to make changes, if it wants to produce and effective work and performance system, as is the hope of increasing the effectiveness of the work and performance of the government bureaucracy by President Jokowi for economic growth and efforts to improve the welfare of the nation's citizens [8].
The operational steps for bureaucratic reform were first carried out by Ministry of Administrative Reform by downsizing bureaucratic. The goal is to streamline bureaucratic work so that it is productive and has high performance. However, the important issues of bureaucratic reform are not limited to trimming the bureaucracy by eliminating echelons III to IV. The main thing is how to build work effectiveness and performance of a dynamic, agile, and professional government bureaucracy to increase effectiveness and efficiency to support government performance to the public.

By considering the ideas and objectives of reducing the bureaucracy, the premise that was built regarding the need for bureaucratic reform through downsizing the bureaucracy is to improve or answer weaknesses that exist in the current bureaucratic structure. It is suspected there are several weaknesses of the bureaucratic structure, namely: First, a fat bureaucratic structure makes policy making and decisions slow. Under these conditions the greater the possibility of miscommunication and mis-coordination. With a simplified bureaucratic structure, officials can be encouraged to innovate and produce. Second, to achieve government accountability. Because it must be admitted, indications of corrupt bureaucratic culture that exploits and misuses their positions still often occur. With the simplified structure, it is hoped that the performance of the bureaucracy will be more efficient and effective. Because after all the fat bureaucratic structure costs a lot. Third, the ultimate goal of simplifying the bureaucracy itself is to build a dynamic bureaucracy that has high flexibility, capability, has a superior culture and a performancebased organization so that it can produce adaptive policies that are integrated into each unit.

Based on the goal of downsizing the bureaucracy, various assumptions, problems, weaknesses, and challenges that exist, researchers consider it important to conduct research on bureaucratic reform implementation models. The Ministry of Administrative Reform is used as a research locus. The reason is as an initiator and pilot of the implementation of bureaucratic downsizing policies. It is hoped that this study can become a pilot model for the implementation LPNK and local governments to carry out bureaucratic reform.

\section{LITERATURE REVIEW}

\section{A. Buraucracy}

Public administration scientists acknowledge that the concept of bureaucracy is an important concept in understanding public administration. Although they have different understandings and points of view in photographing bureaucratic practices in government administration, development, and service to the community.

Bureaucracy has always been the main and important thing in public administration practice. Especially in a modern society like today, where the complexities of state and social life increasingly diverse and the bureaucracy occupies a 
significant position together with the government in power in carrying out various governmental duties and roles.

We can justify the argument as stated by Frederickson [9]. He explained that since modern society experiences social differentiation in social life, monetary increased, the emergence of a capitalist economy, the development of rationality and demystification in society, as well as socio-economic democratization and modernization, various problems always arise and are even more complex, and in that context also then emerged the role of the bureaucracy in response to the needs of the times. In other words, that must be handled, namely technical-administrative functions to coordinate various increasingly complex elements in the process of state administration [9]. This is in line with what Etzioni-Halevy [10] said: "Thus bureaucracy developed, because its rationality and technical superiority made it the most appropriate tool for dealing with the task and problems of complex, modern society". Therefore, if you follow the flow of ideas above, it can be concluded that the more complex problems in modern society, the role of the bureaucracy can be said to always exist and is even more important [10].

According to Haque, Harrop, and Breslin [11], the definition of bureaucracy is an organization consisting of salaried officials who carry out policy decisions [11]. Another thought conveyed by Max Weber that bureaucracy is the most rational form of organization which is expected to be able to create rational organizational processes and systems to ensure an orderly, definite, and easily controlled work mechanism and system for achieving organizational goals. This meaning and system for achieving organizational goals. This meaning illustrates that the bureaucracy is an organization that is expected to have various characteristics capable of acting rationally to achieve organizational goals [12].

From the above understanding it can be interpreted that the bureaucracy is an institution within the state is carried out by individuals who are paid to carry out various roles which include making policies or regulations, administering government from central to regional, implementing development, providing public services, and empowering the community based on various the provisions of the applicable laws and regulations. This meaning implies that the bureaucracy is an institution within the state which contains people and officials who are paid and employed by the state to provide advice and implement public policy.

\section{B. Bureaucratic Reform}

The terminology of bureaucratic reform has been widely discussed. But in fact, this term is derived from a term know as administrative reform. If we borrow the thoughts of Riggs [13] in his book "frontiers of Development Administration", administrative reform is a concept used by developing countries to reform government administration in developing countries [13]. This was because the government administration at that time was deemed incapable of carrying out development sponsor by world donor agencies. Even ten years before that, namely in 1961, Ralph Braibanti had also put forward the concept of administrative reform in developing countries are focused on analysis aimed at (development of administrative capabilities), namely public administration [14].

Meanwhile, according to Caiden [15], in his book "Administrative Reform Comes of Age" also puts forward the same tone regarding the concept of administrative reform. Here, Caiden sees that the background for administrative reform in developing countries is due to the inability of the government to manage foreign loans, so that the donor countries suggest the need for administrative reform, reorganization and revitalization of public companies, and modernization of their management processes. The goal of these activities is to modernize government administration to increase the capacity of government administration for state development and improve people's lives for better [15]. A similar view was expressed by Farazmand [16] in his book "Administrative Reform in Developing Nations". The emphasis is more on reforms and fundamental changes to increase the structure and process of administrative systems capabilities [16].

From the various thoughts of these experts, we can conclude that administrative reform has the following characteristics, namely: first, administrative reform is related to efforts to build administrative capacity; second, the locus that is emphasized is government administration; and the third objective is to increase the capacity of government administrations in the development of a country and a better life for the people. However, according to the ideas of Illchman and Bhargava because the characteristics of administrative reform are related to development in a broad sense, it is necessary to see that the efforts made by the government must be approached with a comprehensive, systemic and integrated approach. This is because development also depends on political, social, economic, and social structure objectives. Therefore, there needs to be a balance in the administrative reform process. This means that the administrative system that is built does not only consist of a collection of separate subsystems (parts), but also involves interactions and interdependence between subsystems or other dimensions [17].

At this level, administrative reform is not just a bureaucratic reform but also involves various other dimensions. However, the locus of emphasis lies in the government bureaucracy. Therefore, it is recognized by Riggs [13] that many experts tend to equate bureaucracy and administrations. As a result, they cannot distinguish between administrations reform and bureaucratic reform.

Apart from the above discussion, the point is that bureaucratic reform requires changes to the bureaucracy that can be done in various ways with certain goals. According to Kim [18], bureaucratic reform can be carried out in various ways, such as: first, reorganization, which is a way to streamline the structure and functions of government organizations. Second, agencification, which is a way to improve customers-oriented service delivery. Agencification strongly fosters a performance-oriented culture in government. 
Third, deregulation, which is the way in which the process of revoking or reducing state regulation, usually regulations related to the economic sphere. Fourth, Personnel reform, namely: a reform plan that calls for the introduction of the private sector competition system into the public sector. Fifth, pay reform, namely: the government needs to reward bureaucrats financially for excelling in their work. It takes a balance of incentives and disincentives or bureaucrats to calculate their own "risk return equation". Sixth, downsizing, namely: how to streamline the bureaucratic structure to regain competitiveness. Seventh, cultural and behavioural change, namely: the government seeks to change the attitudes and behaviour of government officials to improve the quality of government services [18]

The objectives of bureaucratic reform include: (1). Administrative efficiency, in the sense of saving money that can be achieved through simplifying forms, can be achieved through simplifying forms, changing procedures, eliminating duplications, and organizing activities through other methods; (2). Elimination of weaknesses or diseases of state administration such as corruption, favouritism, and friend systems in the political system, etc.; (3). Introduction and promotion of merit systems, data processing through automated systems, increasing use of scientific knowledge, and so on; (4) Adjusting the state administrations system to increase public complaints; (5) Changing the division of labour between the state administrative system and the political system, such as increasing the professional autonomy of the state administrative system and increasing its influence on a policy; (6). Changing the relationship between the administrative systems and the population, for example through the relocation of the centre of power (bias between centralization and decentralization, democratization, etc.) [19]

For Indonesia, the objectives of bureaucratic reform are first, as a government effort to create a lean and efficient system. With a simple bureaucratic system, people can do all kinds of administrative matters more easily and quickly. Second, creating cheap public services that are accessible to all people. In this case, the government will take various means, from structuring regulations to governance that relies on digital technology. Third, as an effort to boost economic growth in Indonesia. Fourth, creating a professional government bureaucracy with characteristics, integrated, high-performance, free, and clean from corruption, neutral, prosperous, dedicated, and upholds the basic values and code of ethics of the state apparatus. Fifth, realizing a management (business process) that is more in line with the principles of good governance [20]. Therefore, it is simply hoped that the goals of bureaucratic reform are adjusted to the contextual problems in each government agency, both at the central and regional levels. So that the professionalism that is expected for the bureaucratic apparatus in building a high-performing bureaucracy can be realized.

\section{Downsizing Bureaucratic}

Bureaucratic reform to build superior bureaucratic capacity, effective work, and decision-making and high performance, can be carried out in various ways. One way is to downsize bureaucratic.

Many experts state that the organizational structure in an organization is an important element that plays a role in building an organization. In other words, that the organizational structure plays an important role in building an organization, so that the organizational structure can determine service quality and organizational performance. Why is that? Because according to Robbins [21] that the organizational structure describes how tasks will be divided, who reports to whom, formal coordination mechanisms and patterns of interaction to be followed. Furthermore, Robbins said that the organizational structure has three components, namely: Complexity, formalization, and centralization. Complexity means in the organizational structure considering the level of differentiation that exists in the organization including the level of specialization or division of labour, the number of levels in the organization and the extent to which organizational units are geographically dispersed. Formalization means that the organizational structure contains the procedures for how an activity is carried out, what can and cannot be done. Meanwhile, centralization means that the organizational structure contains decision-making authority, whether centralized or decentralized. With these various aspects of explanations, the organizational structure can determine organizational performance and service quality [21]. Therefore structure becomes an important entity for the existence of an organization, performing well or poorly, for any type of organization, both public and private [22,23].

Various ideas related to organizational structure improvement were introduced by experts as an anti-thesis of traditional organizational structures towards implementing bureaucracy using other types of organizational structures. Travica [24], for example, tries to initiate several other types of organizational structures such as: organic organization, adhocracy, network organization and virtual organization [24].

In connection with this research that focuses on bureaucratic reform by streamlining the bureaucratic structure from the hierarchy to the professional (functional), the choice of an adhocracy organizational structure model is considered relevant to be used as a knife of analysis. Adhocracy organizational design is an organic organizational structure model and is managed by professionals with a certain level of expertise. Control in design of an adhocracy organization comes from the other side. The coordination is contrary to Weber's traditional hierarchical organizational structure model which emphasizes the behaviour pattern of hierarchical relationships and the impersonality of relationships between superiors and subordinates that are horizontal and vertical. Such characteristics make certain individuals very useful for sharing knowledge, collaboration, and rapid adaptation. Therefore, Mintsberg [25] and Harney [26] have the view that 
adhocracy is an anti-thesis of Max Weber's traditional bureaucratic theory $[25,26]$.

In another perspective, adhocracy is considered to make organizations more adaptive, flexible, and innovative [27]. Many government organizations see a new managerial rationality in public services, one of which is the innovation movement to streamline the bureaucratic structure to make it more effective and efficient [28].

The adoption of the adhocracy organizational structure model has not been popular in Indonesia, but what is being done at this time seems to be like the idea of the adhocracy organizational structure model. Elimination of structural positions with certain functional positions that have certain professional competencies in their respective fields is expected to make government organizations more effective, agile, professional, and efficient at work so that the expected high organizational performance can be achieved.

\section{RESEARCH METHODOLOGY}

This reach uses a descriptive method in a qualitative research approach. The choice of locus was made at Ministry of Administrative Reform because it is considered a pioneer in the implementation of bureaucratic reform, so it is interesting to study and is expected to become a model for implementing bureaucratic reform in organizations in regional government.

Although this research is not intended to be generalized, it is hoped that from the cases that are portrayed and studies, it can be a learning material for local governments in carrying out bureaucratic reform, specifically related to efforts to streamline their bureaucratic structures.

Because of using a qualitative research approach, several data collection techniques, namely in-depth interviews and focus group discussions with key informants and document review were used in this study [29]. The data collection process is carried out directly in the field and is also carried out virtually through a zoom meeting (contained by covid-19) to key informants who understand the purpose of this research. The data verification used method triangulation and source triangulation [30].

\section{RESULTS AND DISCUSSION}

This reach uses a descriptive method in a qualitative research approach. The choice of locus was made at the Ministry of Administrative Reform because it is considered a pioneer in the implementation of bureaucratic reform, so it is interesting to study and is expected to become a model for implementing bureaucratic reform in organizations in regional government.

Based on various data and information collected and analysed, several things were found in this study. First, that the strategic policy direction for bureaucratic reform in the Ministry of Administrative Reform is never separated from the grand design of bureaucratic reform (GDRB) through
Government Regulation No.81/2010. Even though the current government is under President Jokowi-Amin's rule, the GDRB is strategic foundation for reform direction. Indonesian bureaucracy, including in the context of Ministry of Administrative Reform.

The government's initiative to institutionalize bureaucratic reform within a strategic management framework, if interpreted in fact, is a good effort to implement bureaucratic reform in a structured, planned, and institutionalized manner. The direction of bureaucratic change will be coherence with the objectives of national development itself so that reform efforts can be felt by the public.

The strategic achievements to be achieved based on the data and information obtained include the implementation of government and state organizations that are free of corruption, increase their capacity and accountability, strengthen orientation towards improving public services, government effectiveness, and better performance.

The institutionalization of the policy direction for bureaucratic reform above, in the context of Ministry of Administrative Reform, is carried out through various work programs embodied in eight areas of change, which have continued to be carried out until now. The eight areas of change include: organizational structuring so that all organizational structure are more functional and efficient, management (business processes) that are more in line with the principles of good governance, reconciliation of regulations so as not to overlap and triggering more productivity and institutional conduciveness, management of resources apparatus that is managed professionally and with integrity, and is protected from law violations, effective and constructive supervision, accountable in terms of performance and capacity, oriented towards strengthening public services, and mindset change (change in work culture).

The direction of bureaucratic reform policy in Ministry Administrative Reform is carried out in a planned manner through sixth acceleration programs which include: First, structuring the bureaucracy. Second, structuring the number and distribution of civil servants. Third, improving employee welfare through performance allowances. Fourth, efficiency in use of work facilities and infrastructure. Fifth, increasing transparency and accountability. Sixth, the development of electronic government.

From time to time, it seems that the performance of bureaucratic reform has not been optimal, so the government has again issued a new policy related to bureaucratic reform, namely by bureaucracy downsizing.

Bureaucracy downsizing arises because of the existence of bureaucratic pathologies in the bureaucracy, including in the context of Ministry Administrative Reform, such as the slow, convoluted, unprofessional way of working of the government bureaucracy, work ineffectiveness, and poor performance and slow decision making. 
The objectives of bureaucratic downsizing at the Ministry of Administrative Reform are: (1) to create a more dynamic bureaucracy; (2) accelerate the bureaucratic work system; (3) directing civil servants to focus more on work that is functional so that they can better guarantee good organizational performance; (4) encourage more optimal work effectiveness and efficiency; (5) realizing the professionalism of civil servants. In other words, the goal of bureaucratic downsizing in the Ministry of Administrative Reform is to make the bureaucracy more effective at work so that it is productive and has high performance.

The strategic step taken by the Ministry of Administrative Reform through bureaucracy downsizing is to remove structural positions from echelon III and IV to functional positions. Efforts to bureaucratic downsizing and administrative positions into functional ones are interesting for deeper interpretation and analysis.

We know that the functional positions of civil servants are a group of positions occupied by employees to carry out certain functions in the government bureaucracy in Indonesia. According to Government Regulations number 16 of 1994 concerning Functional Positions for Civil Servants, a functional position is a group of positions containing functions and task related to functional services based on certain expertise and skills. This means that efforts to equalize administrative positions to functional ones should pay consider functions and task related to functional services based on certain expertise and skills.

Based on these considerations, the way civil servants work will be more effective and have high performance. This can happen because civil servants work based on certain expertise and skills in accordance with their service functions. This is an important point that need to be underlined in the context of equalizing administrative positions. Not done carelessly or just an equalization without considering the expertise and skills possessed in accordance with the functional service that the employee performs. If this happens then the spirit and goal of bureaucratic reform in the form of bureaucracy downsizing will only be something utopian. Work effectiveness, work productivity, professionalism and high performance are just a dream. In other words, the aim of bureaucratic downsizing will not be realized in the Ministry of Administrative Reform.

What is done in the Ministry of Administrative Reform, normatively considers the provisions in the process of equalizing administrative positions in functional positions, even though in fact it is still administrative not substantive in the nature. From the information obtained, it is explained that efforts to equalize administrative positions to functional positions are carried out by means of strategic stages, which include: (1) identifying administrative positions in the work unit at Ministry of Administrative Reform; (2) mapping of positions and administrative officials affected by bureaucratic downsizing; (3) mapping of functional positions that can be occupied by administrative official who are affected by bureaucratic downsizing; (4) Alignment of functional position allowance with administrative position allowance by calculating income from an administrative position to a functional position; (5) alignment of functional positions classes with administrative position classes.

The activity of identifying administrative positions in each work unit at the Ministry of Administrative Reform and mapping of positions and administrative officials affected by bureaucratic downsizing, as well as mapping functional positions occupied by administrative officials who are affected by bureaucratic downsizing, should not be limited to issues of data collection and mapping in activities mere administration. Because this initial step is a strategic step to go further in the effort to simplify the bureaucracy in question. It must also be ensured that these administrative officers are also ready for competency tests related to the choice of functional positions to be taken or equalized. Likewise, it is also necessary to ensure that the functional positions offered are related to the functional services available in their respective work units. If this is not the case, the expected professionalism towards the work of these functional officials can be disrupted and this can have an impact on work ineffectiveness and sub-optimal performance. In fact, that is what is expected to be eliminated, when there is a change from an administrative position to a functional position.

The research finds that the strategic steps above have been taken by the Ministry of Administrative Reform. However, in practice, the identification and mapping process is not optimal. There are not all functional positions related to functional technical services in works units in the Ministry of Administrative Reform, most of which lead to service functions related to policy analysis. The characteristics of the types of work in the work unit are more inclined to the policy analysis process and provide policy advice related to the empowerment of the state apparatus and bureaucratic reform. The data show that $80 \%$ of functional positions elected by administrative officers are policy analysts. However, the issue that needs further attention is whether the policy analyst functional officers have the expertise and skills that are appropriate to these functional positions or not? This is because what is done is limited to equalizing administrative positions to functional ones which in practice consider the following criteria: (1) duties and functions of positions relating to functional technical services; (2) duties and functions of positions can be carried out by functional officials; (3) positions based on certain expertise/skills. Meanwhile, the criteria for administrative positions that can be considered for not being equalized are (1) a position that has the duties and functions as head of a work unit with the authority and responsibility for budget use or use of goods/services; (2) positions which have duties and functions related to the authority, legalization, document approval or regional authority.

The equalization carried out in the Ministry of Administrative Reform is that an administrator position is equivalent to a certain functional position with the intermediate expert level. As for the supervisory position, it is equivalent to 
a certain functional position with the level of young expert. As for executors, it is equal to a certain functional position with the level of first expert.

The equalization that is carried out raises questions from various parties regarding the competence of the comparable policy analyst functional officers. This happens because there has not been a competency test related to existing policy analysis positions, both at the intermediate expert level and for the junior expert level. This must be considered in the future if professionalism is expected from these functional officers. Competency tests with the required competency standards would be an important instrument to measure the competency of skills and skills of policy analyst functional officers. And this, there will be coherence with the work effectiveness and performance expected in the future. If it is only enforced through an equalization process without a competency test, then in the future there will be new problems. And this is indicated to begin to emerge. The competency test of each administrative position to a functional position must be carried out if the Ministry of Administrative Reform wants to build a bureaucracy as the goal of bureaucratic development is to create a more dynamic bureaucracy, to accelerate the bureaucratic work system, to direct civil servants to focus more on functional work, encouraging effectiveness and more optimal work efficiency as well as realizing the professionalism of civil servants.

The figure of the bureaucracy that wants to be realized like that, becomes a very important foundation when going further in simplifying the bureaucratic structure. Is it true that the step of equalizing an administration position into a functional one without a competency test can guarantee the realization of the bureaucratic figure in questions? This, in the future, needs serious attention so that the vision and goals of bureaucratic reform through bureaucratic downsizing can be realized.

The empirical description elaborated above means that the Ministry of Administrative Reform aim to build a change from Weber's traditional hierarchical organizational structure to an adhocracy organizational design model. The jargon "poor structure, rich in function" by simplifying the bureaucracy through the removal of structural positions from functional (professional) positions with certain expertise and skills, is in line with the concept of adhocracy organizational design which emphasizes an organic organizational structural model and is managed by professionals with a certain level of expertise. Control in organizational that are no longer too hierarchical will accelerate the way the bureaucracy works to be agile, dynamic, and innovative. Such characteristics certainly make individuals (new functional officials) in the Ministry of Administrative Reform capable of realizing an effective, agile, dynamic, and high performing bureaucracy, as is the vision and goal of bureaucratic development in the future Ministry of Administrative Reform.

Second, in the implementation of bureaucratic reform through bureaucratic downsizing in the Ministry of Administrative Reform, in fact it is faced with various important obstacles including: (1) the availability of functional positions in the work field or functional services at work units are not yet fully available according to the needs of the work field; (2) inadequate formation and functional position map; (3) the existence of an unclear career path; (4) equalization of income from a new functional position has not been implemented properly; (5) competency standard instruments at each functional position level that do not yet exist; (6) the working mechanism in the ne "bureaucratic structure model" has not yet been developed; (7) mental unpreparedness and functional position capacity; (8) new personnel management is not yet available, especially for new functional officers.

Third, the research results found that the effectiveness of the objectives of implementing bureaucracy reform through bureaucracy downsizing cannot be assessed. The various objectives of implementing bureaucratic reform that are expected, such as making the bureaucracy agile, dynamic, focused on functional work and professionalism, cannot yet be assessed in the first year of implementing bureaucracy reform, let alone constrained by the Covid-19 pandemic. The implementation of bureaucracy downsizing is still limited to efforts to equalize administrative positions to functional ones. This effort is considered relatively positive in realizing the vision and goal of bureaucratic development in Ministry of Administrative Reform. Unfortunately, in its implementation there are still various obstacles. Evaluation of the equalization process should be carried out immediately, to then prepare various technical and operational policies, as well as strategic policies to support the process of implementing better bureaucratic downsizing.

\section{ConClusions AND SugGeStions}

Based on the results of the discussion, there are several important conclusions that can be formulated:

- Poor structure with rich functions becomes the strategic policy direction of the Ministry of Administrative Reform. The strategic step taken is to streamline the bureaucratic structure by eliminating administrative positions (echelon III and IV) into functional positions in accordance with their respective duties. This shows that there is an effort from the Ministry of Administrative Reform to change the traditional Weberian bureaucratic structure model towards an adhocracy bureaucratic structure model in the future.

- Bureaucracy downsizing has only been limited to eliminating structural positions (echelon III and IV) by equalizing administrative positions to functional ones. Nor is it based on a planned effort by evaluating the organizational structure of the Ministry of Administrative Reform. Bureaucracy downsizing was more due to the existence of policies from President Joko Widodo regarding bureaucratic reform.

- The availability of technical and operational policy tools related to bureaucratic downsizing is not yet complete, such as the official competency test policy 
which is equalized to certain functional positions, policies regarding career paths related to functional positions, policies regarding what work mechanisms are related to functional officials who also carry out managerial functions on a daily basis.

- There is a positive hope that the effectiveness of the objectives of bureaucracy downsizing can be achieved, although at the initial stage of implementation it cannot be assessed. The strategic steps taken by building an adhocracy organizational design model, relatively guarantee that the goal of building an agile, dynamic, and high-performance bureaucracy will be realized.

The recommendations that can be implemented from the results of this study are:

- The implementation model for downsizing the bureaucratic structure towards an adhocracy bureaucratic structure model in the Ministry of Administrative Reform needs to prepare strategic policy tools, such as changes to Civil Service Management Policies (revised Government Regulation number 11 of 2017 about Civil Service Management), technical and operational policies related to work mechanisms from the new bureaucratic structure, competency standards of functional officials, career paths of functional officials who act as coordinator of task and functions of activities, and technical arrangements for functional official competency tests.

- The Ministry of Administrative Reform must immediately conduct a competency test for administrative officials who are equivalent to certain functional positions. This action was taken to build the professionalism of these functional officers.

- Formulate and prepare career management system and formation so that the unit requirements related to the expected functional positions are in line with the scope and characteristics of the work unit

- The career management system for functional officers must be immediately prepared regarding: what kind of career planning? What are the career development methods? And, what kind of career path?

- The application of the principle of functional officers assigned the task and coordination of functional technical service activities must be in accordance with the scope and characteristics of functional technical services in work unit must be enforced. The application of this principle is the main foundation in building the professionalism of civil servants.

\section{REFERENCES}

[1] The World Bank Group, Worldwide Governance Indicators.Retreived 2019 [Online]. Retrieved from http://info.worldbank.org/governance/wgi/\#home, 2009.

[2] Deputi Bidang Reformasi Birokrasi, Akuntabilitas, dan Pengawasan Laporan Akuntabilitas Kinerja Instansi Pemerintah. Kementerian Pendayagunaan Aparatur Negara, 2020.

[3] Deputi Bidang Kajian Kebijakan Lembaga Administrasi Negara Republik Indonesia, Kajian Grand Disain Public Administration. Jakarta: LAN RI, 2018.

[4] The World Bank Group, Doing Business 2018: Reforming to Create Jobs [Online]. Retreived from: http://www.doingbusiness.org/content/dam/doingBusiness/media/Annua 1-Reports/English/DB2018-Full-Report.pdf, 2018.

[5] KPMG International, Future State: The Global Megatrends Shaping Government. Toronto: KPMG International, 2016.

[6] K. Schwab, The Fourth Industrial Revolution: What it Means, Wow to Response. Crown Business, 2017.

[7] World Economic Forum, The Global Human Capital Report 2017 Creative Commons Attribution - NonCommercial - NoDerivatives 4.0. International Public License, 2017

[8] I. Abdullah, Menyiapkan Kenormalan Baru. UGM Talks: 29 Mei 2020.

[9] H.G. Frederickson, The Spirit of Public Administration. Jossey-Bass Publications, 1997.

[10] E. Etzioni-Halevy, Bureaucracy and democracy (Vol. 7). Routledge, 2013.

[11] B. Setiyono, Birokrasi dalam Perspektif Politik dan Administrasi. Bandung: Nuansa, 2012.

[12] M. Albrow, Birokrasi. alih bahasa M Rusli Karim dan Totok Daryanto. Yogyakarta: Tiara Wacana, 1989.

[13] F.W. Riggs, Frontiers of Development Administration. Duke University Press, 1971

[14] A.F. Leemans, The Management of Change in Government. Institute of Social Study. Netherland: Martinus Nijhoff, 1976.

[15] G.E. Caiden, Administrative Reform Comes of Age. Berlin, New York: Walter de Gruyter, 1991

[16] A. Farazmand, Administrative Reform in Developing Nation. London: Praeger Publishers, 2002.

[17] F.W. Riggs, Frontiers of Development Administration. Duke University Press, 1971

[18] P.S. Kim, "Administrative Reform in the Korean Central Government," Public Performance \& Management Review, vol. 24, no. 2, pp. 145-160, 2013

[19] Y. Dror, Strategies for Administrative Reform: Development and Change. Den Haag: The Hague Press, 1971.

[20] A. Dwiyanto, Reformasi Birokrasi Kontekstual: Kembali ke Jalur yang Benar. Yogyakarta: Gadjah Mada Universtiy Press, 2015.

[21] S.P. Robbins, Teori Organisasi: Struktur, Desain dan Aplikasi, Alih Bahasa Jusuf Udaya. Jakarta: Arcan, 1994.

[22] F. Luthans, Organizational Behavior An Evidence-Based Approach (12th Ed). New York: McGraw Hill, 2011

[23] R.B. Denhardt and T.J. Catlaw, Theories of Public Organization. (7th Ed). Stamford: Cengage Learning, 2015

[24] B. Travica, New Organizational Designs: Information Aspects. Connecticut: Ablex Publising Corporation, 1999.

[25] H. Mintzberg, Structure in Five Designing Effective Organizations. New Jersey: Prentice Hall, 1993.

[26] D.T. Kooij, "Employing the Older Worker," Wiley Encyclopedia of Management, pp. 1-3, 2015 
[27] L.R. Andhika, "Dari Struktur Birokrasi Tradisional ke Model Adhocracy (Struktur Organisasi Inovatif)," Publisia: Jurnal Ilmu Administrasi Publik, vol. 3, no. 1, pp. 25-32, 2018.

[28] G.C. McLoughlin and W.R. Kennedy, A Guide to Innovation Processes and Solution for Government. Boca Rantor FL: CRC Press, 2016.
[29] J.W. Creswell, Research Design: Qualitative-Quantitative and Mixed Methods Approaches. (5th Ed.) Sage Publication, 2017.

[30] N.K. Denzin and S.L. Yvonna, The Sage Handbook of Qualitative Research. Third Edition. London: Sage Publication, 2005. 